\title{
Abdimas Pariwisata
}

Vol.2 No. 2 Tahun 2021

\section{Pengelolaan Hewan Qurban Dengan Protokoler Kesehatan Dalam Rangka Pencegahan Penularan Covid-19}

\author{
Slamet Supriyanto ${ }^{1}$, Lutfi Hendriyati ${ }^{2}$, Tedi Candra Lesmana ${ }^{3}$ \\ ${ }^{1}$ Sekolah Tinggi Pariwisata AMPTA,Yogyakarta, Indonesia, email:slamet700@gmail.com \\ 2 Akademi Pariwisata Yogyakarta, Yogyakarta, Indonesia, email:lutfihendriyati.slamet@gmail.com \\ ${ }^{3}$ STIKES WIRA HUSADA,Yogyakarta,Indonesia, email:tedylesmana58@yahoo.co.id
}

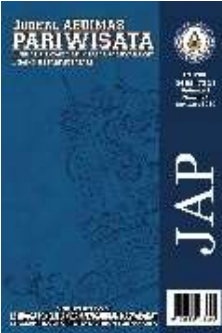

\begin{tabular}{l}
\hline Informasi artike \\
\hline Sejarah \\
artikel \\
Diterima \\
Revisi \\
Dipublikasikan \\
\hline Kata kunci: \\
Hewan Qurban \\
Penyembelihan \\
Covid-19 \\
Protokol Kesehatan \\
\\
\\
Keywords: \\
Qurban Animals \\
Slaughter \\
Covid-19 \\
Health Protocols
\end{tabular}
\begin{abstract}
ABSTRAK
Kegiatan Pengabdian Masyarakat ini bertujuan untuk menularkan pengetahuan tentang tehnik penanganan hewan qurban (Terutama Kambing) yang sederhana kepada Masyarakat serta memberi pengetahuan tentang teknik tata cara penyembelihan hewan Qurban dan pemilihan alat penyembelih yang tepat agar dapat dicontoh oleh juru sembelih di masyarakat dengan protokoler kesehatan dalam upaya mencegah penularan covid-19. Dalam Kegiatan ini menggunakan metode diskusi dan praktek langsung dilapangan. Hasil dari rangkaian kegiatan pengabdian ini Panitia Qurban mampu menyembelih hewan qurban dan memilih alat potong yang baik sesuai syariat Islam dan dengan protokoler kesehatan.
\end{abstract}

\begin{abstract}
Management of Sacrificial Animals With Health Protocols In The Context of Preventing The Spread of Covid-19

This Community Service activity aims to transmit knowledge about techniques for handling sacrificial animals (Especially Goat) that are simple to the community and provide knowledge about techniques for slaughtering Qurban animals and the selection of the right slaughtering tools so that slaughterers in the community can imitate them with health protocols in an effort to prevent the transmission of COVID-19. In this activity using the method of discussion and direct practice in the field. As a result of this series of service activities, the Qurban Committee was able to slaughter sacrificial animals and choose good cutting tools according to Islamic law and health protocols.
\end{abstract}

\section{Pendahuluan}

Penyebaran Pandemi Covid-19 di Indonesia saat ini masih terjadi, diperlukan upaya untuk mencegah penularan Covid-19 di masyarakat. Beberapa cara yang bisa dilakukan untuk mencegah penularan virus ini adalah: Menjaga kesehatan dan kebugaran agar stamina tubuh tetap prima dan sistem imunitas / kekebalan tubuh meningkat. Mencuci tangan dengan benar secara teratur menggunakan air mengalir dan sabun atau hand-rub berbasis alkohol. Mencuci tangan sampai bersih selain dapat membunuh virus yang mungkin ada di tangan kita, tindakan ini juga merupakan salah satu tindakan yang mudah dan murah. Sekitar 98\% penyebaran penyakit bersumber dari tangan. Karena itu, menjaga kebersihan tangan adalah hal yang sangat penting. Ketika batuk dan bersin, tutup hidung dan mulut Anda dengan tisu atau lengan atas 
bagian dalam (bukan dengan telapak tangan). Hindari kontak dengan orang lain atau bepergian ke tempat umum. Hindari menyentuh mata, hidung dan mulut (segitiga wajah). Tangan menyentuh banyak hal yang dapat terkontaminasi virus. Jika kita menyentuh mata, hidung dan mulut dengan tangan yang terkontaminasi, maka virus dapat dengan mudah masuk ke tubuh kita.Gunakan masker dengan benar hingga menutupi mulut dan hidung ketika Anda sakit atau saat berada di tempat umum. Buang tisu dan masker yang sudah digunakan ke tempat sampah dengan benar, lalu cucilah tangan Anda. Menunda perjalanan ke daerah/ negara dimana virus ini ditemukan. Hindari bepergian ke luar rumah saat Anda merasa kurang sehat, terutama jika Anda merasa demam, batuk, dan sulit bernapas. Segera hubungi petugas kesehatan terdekat, dan mintalah bantuan mereka. Sampaikan pada petugas jika dalam 14 hari sebelumnya Anda pernah melakukan perjalanan terutama ke negara terjangkit, atau pernah kontak erat dengan orang yang memiliki gejala yang sama. Ikuti arahan dari petugas kesehatan setempat. ( Sumber https://www.kemkes.go.id/folder/view/full-content/structure-faq.html diakses tgl 27/07/2021)

Hari raya Idul Adha atau juga dinamakan Idul Qurban adalah hari raya umat islam. Qurban berasal dari bahasa Arab, "Qurban" (قربان), yang berarti dekat. Di dalam ajaran Islam, qurban disebut juga dengan al-udhhiyyah dan adh-dhahiyyah yang berarti binatang sembelihan, seperti unta, sapi atau kerbau, dan kambing yang disembelih pada hari raya Idul Adha dan hari-hari tasyriq sebagai bentuk taqarrub atau mendekatkan diri kepada Allah.

Dalam perspektif syari'at (fiqh), qurban memiliki makna ritual, yakni menyembelih hewan ternak yang telah memenuhi kriteria tertentu dan pada waktu tertentu, yaitu pada hari nahar (tanggal 10 Dzulhijah) dan hari tasyrik (tanggal 11-13 Dzulhijah). ... ibadah qurban harus dengan hewan qurban, seperti kambing, sapi atau unta, dan tidak boleh diganti dengan lainnya, seperti uang atau beras (Syukri, 2012)

Nabi bersabda bahwa qurban merupakan sunnah kaum muslimin (Al Utsaimin, 2003, hlm. 16). Oleh karena itu, umat Islam bersepakat bahwa berqurban itu disyariatkan, sebagaimana keterangan beberapa ulama. Namun terdapat perbedaan pendapat ulama tentang hukumnya, ada yang mengatakan wajib bagi yang memiliki kelapangan rezeki, ada pula yang mengatakan sunah mu'akadah. Jika dijabarkan, kedua pendapat yang berbeda ini masing-masing mempunyai dasar yang sama kuat. Sebagian ulama memberikan jalan keluar dari perselisihan dengan menasehatkan, “...selayaknya bagi mereka yang mampu, tidak meninggalkan berqurban. Karena dengan berqurban akan lebih menenangkan hati dan melepaskan tanggungan, wallahu a'lam" (Baits, 2008).

Idul Adha jatuh pada tanggal 10 bulan Zulhijah atau 70 hari setelah idul fitri Pada hari idul adha, Penyembelihan hewan harus sesuai dengan tuntunan Islam. Jika tidak akan berdampak pada kehalalan daging tersebut, syarat syarat penyembelihan yang wajib dipenuhi bagi kehalalan mengkonsumsi daging hewan sembelihan terkait dengan juru sembelih (Penyembelih), alat sembelihan, anggota tubuh yang disembelih dan tata cara penyembelihan (Qordhowi 2007). Juru sembelih (penyembelih) menurut Peraturan menteri Pertanian Republik Indonesia No. 114/Permentan/PD.410/9/2014 yaitu beragama Islam dan sudah Akhil Baligh, memiliki keahlian dalam menyembelih dan memahami tata cara penyembelihan secara syar'i.

Perayaan Hari Raya Idul Adha tahun tahun 2021 masih dalam suasana pandemi Covid19, sehingga pelaksanaan di Perum Taman Sedayu III RT 69 Metes Argorejo Sedayu Bantul Yogyakarta mengacu pada pedoman dan dari Peraturan Mentri Kesehatan Republik Indonesia Nomor HK.01.07/Menkes/382/2020, tentang Protokol Kesehatan Bagi Masyarakat do Tempat 
dan Fasilitas Umum Dalam Rangka Pencegahan dan Pengendalian Corona Virus Disease 19 (Covid-19).

Penyelenggaraan pemotongan dan pengelolaan hewan qurban tahun ini di Mushola $\mathrm{Al}$ Barokah Perum Taman Sedayu II RT 69 Metes Argorejo Sedayu Bantul berbeda dari tahun sebelumnya. Akibat Covid-19 Membuat kesadaran Masyarakat akan kebersihan, kesehatan dan kelestarian lingkungan sangat besar (Hendriyati, Santoso:2021). Dengan adanya kesadaran dari masyarakat membuat penyelenggaraan idul qurban tahun ini dilaksanakan dengan sederhana dengan memperhatikan protokoler kesehatan. Panitia penyelenggaraan pemotongan hewan qurban tahun ini memutuskan hanya melibatkan panitia terbatas, tidak melibatkan semua warga, hanya dilaksanakan 10 orang selaku panitia, dengan jumlah hewan qurban sebanyak 7 kambing/ domba.

Pembatasan partisipasi warga dimaksudkan untuk meminimalisir kerumunan masyarakat. Pengelolaan hewan qurban dengan protokoler Kesehatan diharapkan dapat mencegah penyebaran covid-19. Dari latar belakang diatas maka pengabdian Kepada Masyarakat kali ini mengambil judul "Pengelolaan Hewan Qurban Dengan Protokoler Kesehatan Dalam Rangka Pencegahan Penularan Covid-19”.

Kegiatan pengabdian ini bertujuan untuk menularkan pengetahuan tentang pemilihan alat penyembelihan dan Pengelolaan hewan qurban (Terutama Kambing) yang sederhana kepada Masyarakat agar dapat dicontoh oleh juru sembelih di masyarakat dengan menerapkan protokoler kesehatan dalam upaya menyegah penularan covid-19

\section{Metode}

Untuk mencapai tujuan kegiatan., Penyelenggaraan pengabdian masyarakat di Lingkungan Musholla Al Barokah Rt.69 Metes, Argorejo, Sedayu, Bantul, dengan Menggunakan metode:1. Diskusi, Diskusi dilakukan untuk kemudahan dan kelancaran yang harus disiapkan selama kegiatan berlangsung. Memberikan gambaran tehnik penyembelihan dan pengelolaan dengan alat sembelih yang tepat dan cara mengasah pisau sembelih yang benar serta alat protokoler kesehatan yang diperlukan misalnya sabun/hand sanitizer, Masker, Sarung tangan dan lain lain. Menurut Samani (2012) Diskusi adalah pertukaran pikiran (Sharing Of Opinion) antara dua orang atau lebih yang bertujuan memperoleh kesamaan pandang tentang sesuatu masalah yang dirasakan bersama. 2. Praktek Lapangan. Pelaksanaan Praktek berlangsung di gedung serbaguna taman sedayu III Rt. 69 dengan menggunakan pisau sembelih. Dengan melibatkan panitia qurban yang berasal dari Musholla Al Barokah RT. 69, Metes, Argorejo, sedayu, Bantul.

\section{Hasil dan Pembahasan}

Pahala qurban seekor kambing dapat mencakup sebuah keluarga dan ditambah dengan muslim lain yang dikehendaki dari luar keluarga, sebagaimana diungkap dalam hadits 'Aisyah ra. yang diriwayatkan Muslim, sesungguhnya Nabi saw memerintahkan agar dibawakan kambing kibasy bertanduk, bulu kakinya berwarna hitam, bulu di sekitar mata serta di kanan kiri lambung juga berwarna hitam.

Qurban Mulyana Abdullah Jurnal Pendidikan Agama Islam -Ta'lim Vol. 14 No. 1 - 2016111 Kambing tersebut akan beliau jadikan sebagai hewan qurban. Kemudian Nabi bersabda kepada 'Aisyah:Wahai 'Aisyah, ambilkan pisau besar!" Setelah pisau itu dibawakan, Nabi mengambilnya dan membaringkan kibasy lalu (bersiap untuk) menyembelihnya. Kemudian beliau berkata, "Dengan nama Allah, wahai Allah terimalah dari 
Muhammad, keluarga Muhammad dan ummat Muhammad", kemudian beliau menyembelihnya (Al Utsaimin, 2003, hlm. 41)

Syarat kesehatan kambing qurban menurut islam sesuai sabda Rasulullah saw "Ada empat penyakit pada binatang kurban yang dengannya kurban itu tidak mencukupi. Yaitu yang buta dengan kebutaan yang nampak sekali, dan yang sakit dan penyakitnya terlihat sekali, yang pincang sekali, dan yang kurus sekali” (HR Tirmidzi dalam Ishomuddin, 2008)

Pendampingan pelaksanaan pengelolaan hewan Qurban dengan Protokoler Kesehatan yang dilaksanakan di gedung serbaguna RT.69 Metes, Argorejo, Sedayu Bantul. Berjalan dengan baik dan lancar. Hasil dari kegiatan pengabdian masyarakat ini meliputi 1. Pemilihan Alat penyembelihan hewan Qurban. 2. Tehnik Penyembelihan Hewan Qurban dengan Menjalankan protokoler kesehatan dalam rangka mencegah penyebaran covid-19. Hasil kegiatan tersebut dapat kami jabarkan sebagai berikut: Pertama. Panitia Qurban atau juru sembelih RT. 69 dapat memilih alat penyembelih hewan qurban dengan benar dan tepat. Alat penyembelihan merupakan salah satu syarat yang diharuskan dalam proses penyembelihan. Alat penyembelih diisyaratkan merupakan alat yang tajam dan sekiranya mempercepat kematian hewan serta meringankan rasa sakit hewan yang disembelih. Alat penyembelihan diwajibkan selalu dalam keadaan tajam supaya dapat memotong dan mengalirkan darah dengan deras sekali dari sayatan pada leher agar tidak terlalu menyakitkan dan mempercepat kematian hewan sembelihan. Ukuran pisau potong yaitu $30 \mathrm{~cm}$ untuk sapi dan $20 \mathrm{~cm}$ untuk domba/kambing (Arif:2019). Kemudian uji ketajaman pisau tersebut dengan menggunakan kertas. Kedua, Pengelolaan hewan qurban meliputi tehnik penyembelihan, menguliti, pemisahan daging kurban dan pembagian hewan qurban. Panitia atau juru sembelih dapat melakukan penyembelihan hewan qurban sesuai dengan tuntunan Islam. Penyembelihan dilakukan dengan memotong putus 3 bagian dari leher secara cepat yaitu saluran makanan dan minuman yang berada dibawah tenggorokan (mari'), saluran pernafasan dan tenggorokan (hulqum)dan dua urat leher yaitu dua urat yang berada pada dua sisi leher yang mengelilingi tenggorokan yang merupakan dua pembuluh darah arteri dan Vena (wadajain). Tehnik Penyembelihan hewan Qurban di Rt. 69 Metes dilaksanakan sebagai berikut:

1. Hewan Qurban diusahakan ditata dengan rapi serta diusahakan tempat memotong dengan tempat hewan yang belum dipotong terpisah dengan harapan hewan qurban tersebut tidak melihat hewan lain dipotong.

2. Menyiapkan pisau sembelih yang sangat tajam (bukan sekedar tajam), diuji dengan memotong tisu atau kertas A4, akan lebih baik bila dapat memotong kapas atau plastik, bila kurang tajam pisau diasah sampai ketajaman yang diinginkan.

3. Posisi hewan yang akan disembelih membujur dengan menghadap kiblat.

4. Memeriksa kesiapan hewan qurban seperti tali yang mengikat dileher yang tidak perlu untuk di potong (dihilangkan).

5. Pisau yang digunakan dalam memotong hewan qurban jangan ditampakan ke hewan qurban.

6. Memotong qurban dengan cara yang baik dan cepat, sesuai sunah dan juru potong menempatkan hewan qurban adalah sesuatu yang istimewa dan tidak sembarangan (sejarah Nabi Ibrahim yang akan menyembelih Ismail)

7. Membaca Doa dengan menyebut nama Allah SWTsebelum dilakukan penyembelihan membaca sholawat Nabi (Allahumma sholli ala Muhammad wa ala ali Muhammad), dilanjutkan membaca (Bismillahi allahuakbar) kemudian membaca doa menyembelih hewan qurban dengan menyebutkan nama Shohibul qurban (Bismillahi allohumma wa allohuakbar, Allohumma hadza minka wailaika, faqobbal minni fulan wa alii fulan). 
8. Juru potong atau jagal memposisikan diri dibelakang kambing yang sudah ditidurkan menghadap kiblat.

9. Atur posisi leher kambing dengan cara kepala kambing ditarik sedikit kearah kiri agak serong keatas agar leher membentuk sudut kurang lebih 30 derajat agar saat penyembelihan 2 urat leher dan saluran nafas serta saluran makanan mudah terpotong.

10. Metode potong tarik, tutup mata kambing menggunakan telinga kambing, genggam pisau dengan ibu jari kearah ujung pegangan, mata pisau menghadap juru potong, kemudian arahkan pisau dibawah leher qurban posisi diurat leher qurban bawah, tempelkan kekulit leher dan tarik dengan cepat sambil melingkari leher depan sampai urat leher samping, usahakan satu kali tarik, sebelum pisau diangkat, pastikan 2 urat leher dan saluran nafas serta saluran makanan terputus (sehingga pembuluh darah besar otomatis terpotong).

11. Metode potong dorong, tutup mata kambing dengan telinga kambing, genggam pisau dengan ibu jari kearah bilah pisau, mata pisau menghadap bawah, kemudian arahkan pisau atas leher qurban posisi diurat leher qurban atas, tempelkan kekulit leher dan dorong dengan rapi, cepat sambil melingkari leher depan sampai urat leher samping, usahakan satu kali dorong, sebelum pisau diangkat, pastikan 2 urat leher dan saluran nafas serta saluran makanan terputus (sehingga pembuluh darah besar otomatis terpotong).

12. Kegiatan qurban tanggal 20 Juli 2021, panitia yang terlibat dan bersentuhan dengan qurban diwajibkan untuk menggunakan masker dan sarung tangan.

Menyembelih qurban termasuk amal salih yang paling utama. Ibunda 'Aisyah radhiyallahu'anha menceritakan bahwa Nabi shallallahu 'alaihi wa sallam bersabda, "Tidaklah anak Adam melakukan suatu amalan pada hari Nahr (Iedul Adha) yang lebih dicintai oleh Allah melebihi mengalirkan darah (qurban), maka hendaknya kalian merasa senang karenanya." (HR. Tirmidzi, Ibnu Majah dan Al Hakim dengan sanad sahih, lihat Taudhihul Ahkam, IV/450) dalam (M. Sirojuddin Cholili,2016).

Protokoler Kesehatan dalam pengelolaan Qurban, Cara yang bisa dilakukan untuk mencegah penularan virus ini adalah: Menjaga kesehatan dan kebugaran agar stamina tubuh tetap prima dan sistem imunitas / kekebalan tubuh meningkat. Mencuci tangan dengan benar secara teratur menggunakan air dan sabun atau hand-rub berbasis alkohol. Mencuci tangan sampai bersih selain dapat membunuh virus yang mungkin ada di tangan kita, tindakan ini juga merupakan salah satu tindakan yang mudah dan murah. Sekitar 98\% penyebaran penyakit bersumber dari tangan. Karena itu, menjaga kebersihan tangan adalah hal yang sangat penting. Ketika batuk dan bersin, tutup hidung dan mulut Anda dengan tisu atau lengan atas bagian dalam (bukan dengan telapak tangan). Hindari kontak dengan orang lain atau bepergian ke tempat umum. Hindari menyentuh mata, hidung dan mulut (segitiga wajah). Tangan menyentuh banyak hal yang dapat terkontaminasi virus. Jika kita menyentuh mata, hidung dan mulut dengan tangan yang terkontaminasi, maka virus dapat dengan mudah masuk ke tubuh kita.Gunakan masker dengan benar hingga menutupi mulut dan hidung ketika Anda sakit atau saat berada di tempat umum. Buang tisu dan masker yang sudah digunakan ke tempat sampah dengan benar, lalu cucilah tangan Anda. Menunda perjalanan ke daerah/ negara dimana virus ini ditemukan. Hindari bepergian ke luar rumah saat Anda merasa kurang sehat, terutama jika Anda merasa demam, batuk, dan sulit bernapas. Segera hubungi petugas kesehatan terdekat, dan mintalah bantuan mereka. Sampaikan pada petugas jika dalam 14 hari sebelumnya Anda pernah melakukan perjalanan terutama ke negara terjangkit, atau pernah kontak erat dengan orang yang memiliki gejala yang sama. Ikuti arahan dari petugas kesehatan setempat. ( Sumber https://www.kemkes.go.id/folder/view/full-content/structure-faq.html diakses tgl 27/07/2021). 
Tabel 1. Hasil kegiatan

\begin{tabular}{|c|c|c|c|c|}
\hline No & Kegiatan & Parameter Diamati & Hasil & Keterangan \\
\hline 1 & $\begin{array}{l}\text { Pemilihan Alat } \\
\text { Penyembelihan }\end{array}$ & $\begin{array}{l}\text { Pemahaman } \\
\text { Aplikasi/praktek } \\
\text { Kepuasan } \\
\text { Kesulitan }\end{array}$ & $\begin{array}{l}+ \\
+ \\
+ \\
-\end{array}$ & $\begin{array}{l}\text { Panitia/Masyarakat mampu } \\
\text { memilih alat potong yang baik } \\
\text { dan }\end{array}$ \\
\hline 2 & $\begin{array}{l}\text { Pengelolaan Hewan } \\
\text { Qurban }\end{array}$ & $\begin{array}{l}\text { Pemahaman } \\
\text { Aplikasi/praktek } \\
\text { Kepuasan } \\
\text { Kesulitan }\end{array}$ & $\begin{array}{l}+ \\
+ \\
+ \\
-\end{array}$ & $\begin{array}{lr}\text { Juru Sembelih dan panitia } \\
\text { mampu mempraktekkan tehnik } \\
\text { penyembelihan } & \text { seperti: } \\
\text { meletakan } & \text { posisi } \\
\text { (memposisikan) } & \text { qurban, } \\
\text { memegang alat potong dan } \\
\text { proses kegiatan memotong. }\end{array}$ \\
\hline 3 & Protokoler Kesehatan & $\begin{array}{l}\text { Pemahaman } \\
\text { Aplikasi/praktek } \\
\text { Kepuasan } \\
\text { Kesulitan }\end{array}$ & $\begin{array}{l}+ \\
+ \\
+ \\
-\end{array}$ & $\begin{array}{lr}\text { Panitia/ Masyarakat mampu } \\
\text { melaksanakan pengelolaan } \\
\text { hewan qurban } \\
\text { menerapkan } \\
\text { Kesehatan }\end{array}$ \\
\hline
\end{tabular}

Kegiatan pengabdian Masyarakat ini dilaksanakan sesuai jadwal yang telah ditentukan dan berjalan dengan lancar. Panitia Kegiatan adalah Takmir Masjid Musholla Al-Barokah RT.69 Metes, Argorejo, Sedayu, Bantul. Kegiatan pengabdian Masyarakat ini diawali dengan briefing satu hari sebelum hari raya idul adha. Hal ini dilakukan agar pada saat Penyembelihan hewan Qurban dapat berjalan dengan lancar . Penyampaian materi dilakukan sambil berdiskusi dengan panitia Qurban kemudian dilanjutkan dengan kerjabakti dengan membuat lubang dan tempat untuk menggantung kambing yang telah di sembelih. Penyampaian Materi terkait dengan persiapan protokoler kesehatan, Tempat penyembelihan hewan Qurban dan tempat pembagian hewan qurban.

Panitia Qurban dan warga setempat bekerjasama dalam penyembelihan hewan Qurban dan saling mengingatkan untuk protokoler kesehatan misalnya menggunakan masker, sarung tangan, cuci tangan pakai sabun.

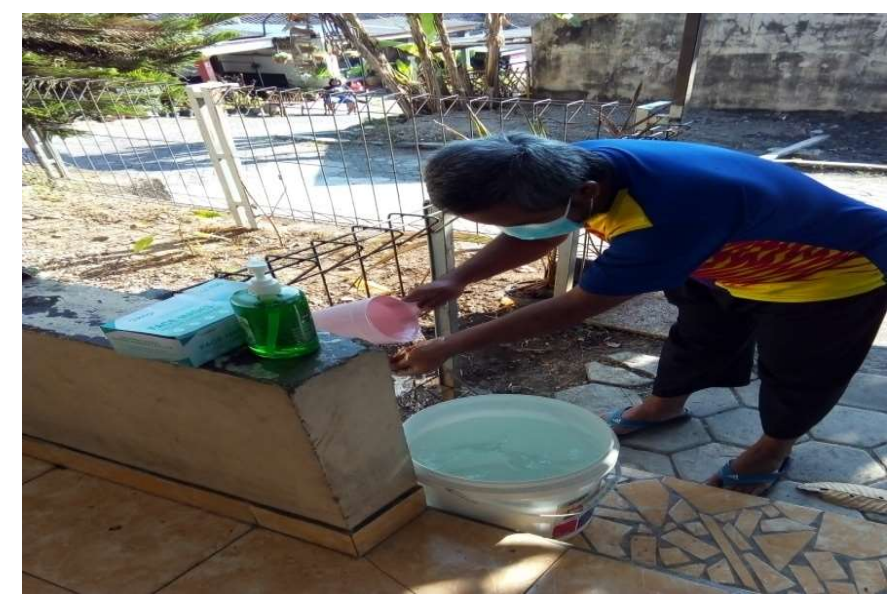

Gambar 1. Sebelum Memulai Kegiatan cuci tangan pakai sabun Sumber : Dokumentasi Penulis, 2021 


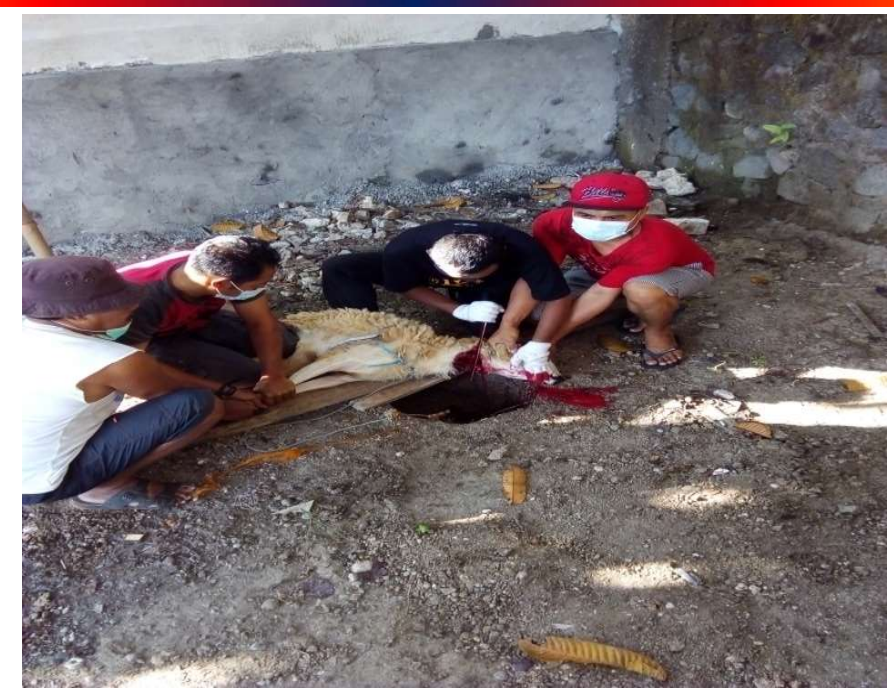

Gambar 2. Penyembelihan Hewan Qurban

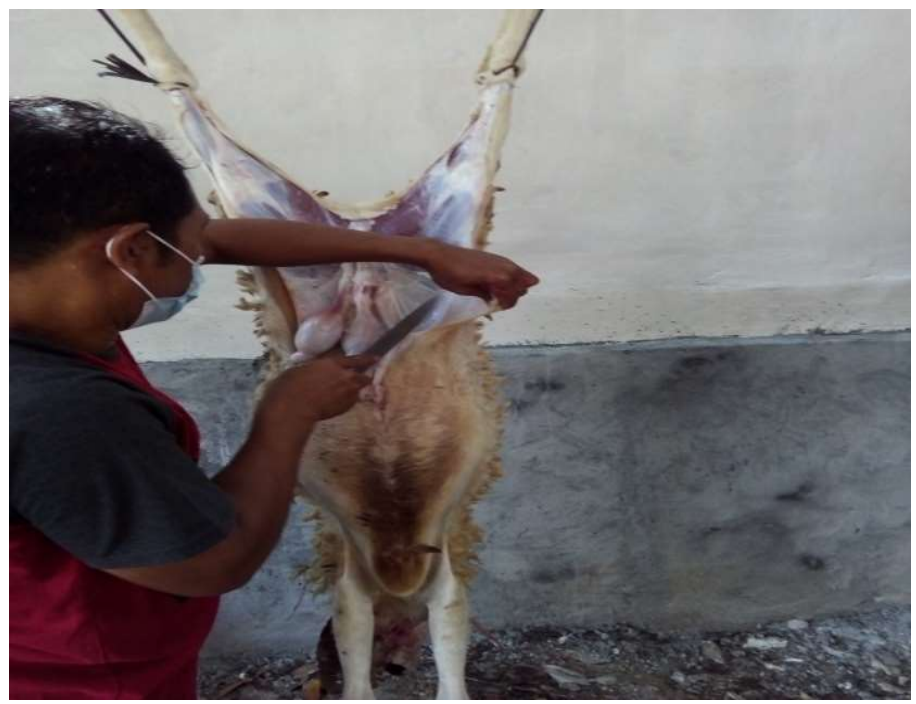

Gambar 3. Proses menguliti hewan qurban

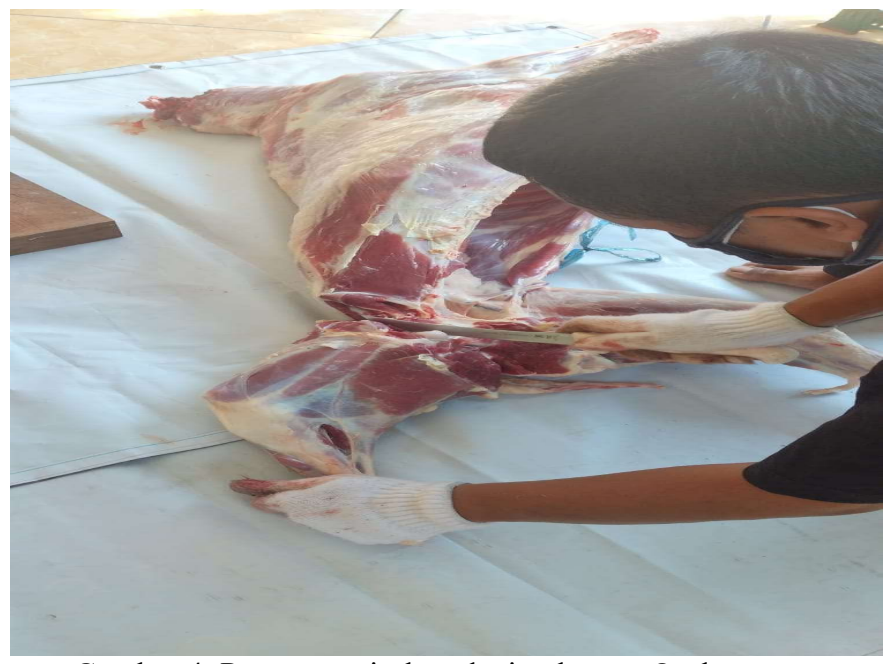

Gambar 4. Proses pemisahan daging hewan Qurban 


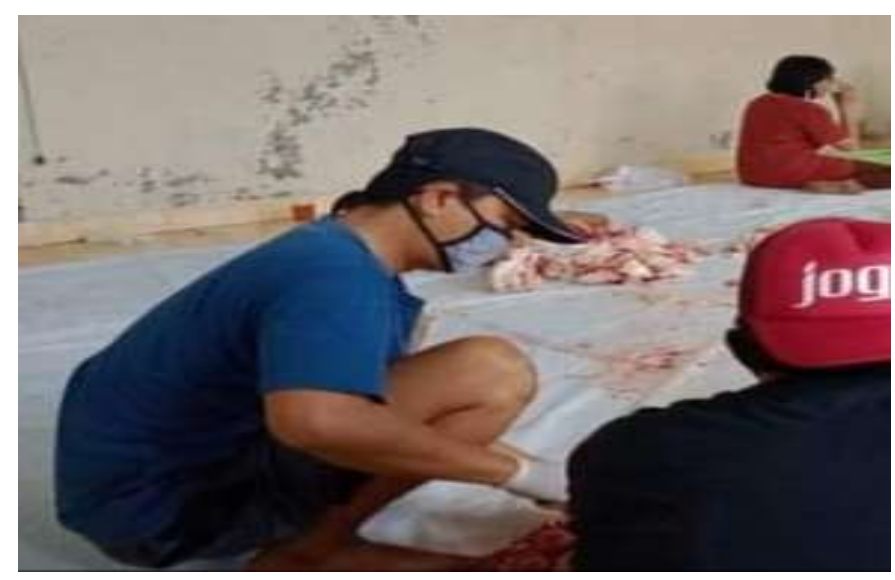

Gambar 5. Proses Pembagian Hewan Qurban

Kegiatan ini merupakan pendampingan yang dilaksanakan oleh Tim Dosen karena adanya kekhawatiran masyarakat khususnya warga perumahan Taman Sedayu III RT.69 Metes Argorejo, Sedayu Bantul terhadap penyebaran covid-19, Walaupun dilaksanakan dengan cara sederhana dan melibatkan sedikit panitia, kegiatan ini berjalan secara tertib,aman dan lancar.

\section{Simpulan}

Program pengabdian masyarakat yang dilakukan oleh Tim Dosen dan Panitia Qurban Musholla Al-Barokah RT.69 Metes Argorejo sedayu Bantul cukup memberikan hasil yaitu Panitia Qurban dapat memilih alat penyembelih dengan tepat dan benar hal ini dapat dilihat dari Penyembelihan hewan qurban. Juru Sembelih dan panitia mampu mempraktekkan tehnik penyembelihan seperti: meletakan posisi (memposisikan) qurban, memegang alat potong dan proses kegiatan memotong sampai dengan pembagian hewan qurban. Kegiatan ini dari persiapan hingga pelaksanaan dilaksanakan dengan menerapkan protokoler kesehatan.

\section{Referensi}

Abdullah,M. (2016). Qurban Wujud Kedekatan Seorang Hamba Dengan Tuhannya, Jurnal Pendidikan Agama Islam-Ta'lim, 14(1). URL: http://jurnal.upi.edu/file/07 Qurban_Mulyana.pdf

Arif, Ridi. (2019). Buku Saku Panduan Praktis Ibadah Kurban. Bandung: Sekretariat Panitia Kurban FKH IPB

Al Utsaimin, M. S. (2003). Tatacara Qurban Tuntunan Nabi saw. Terjemahan: Aris Munandar. Jogjakarta: Media Hidayah

Ammi Nur Baits (2009) Panduan Ibadah Qurban (bagian 2). dipetik tanggal 22 November 2015. URL: https://muslim.or.id/1597-panduan-ibadah-qurbanbagian-2.html

Baits, A. N. (2008) Fiqih Qurban. dipetik tanggal 22 November 2015. url https://muslim.or.id/446-fiqih-qurban.html. 
Baits, A. N. (2009) Panduan Ibadah Qurban (bagian 1). dipetik tanggal 22 November 2015 dari. URL: https://muslim.or.id/1593-panduan-ibadah-qurbanbagian-1.html

Cholili, MS. (2016) Problematika Seputar Ibadah Qurban, Jurnal Program Studi PGMI Volume 3, Nomor 2, September 2016 P-ISSN: 2442-3661E-ISSN:2477-667X, file://C:/Users/acer/AppData/Local/Temp/68-Article\%20Text-156-1-10-20170410.pdf

Hendriyati, L., \& Santoso, I. B. (2021). Strategi Pemasaran Food and Beverage untuk Meningkatkan Penjualan pada Masa Pandemi Covid-19 di Cavinton Hotel Yogyakarta Indonesia. Journal of Tourism and Economic, 4(1), 60-72. https://doi.org/https://doi.org/10.36594/jtec.v4i1.111.

Ishomuddin. (2014) Pengertian Qurban Secara Lengkap dengan Penjelasannya. dipetik tanggal 19 November 2015 dari http://shofaabdillah. blogspot.com/2014/09/pengertian-qurban-secara-lengkap-dengan.html.

Peraturan menteri Pertanian Republik Indonesia No. 114/Permentan/PD.410/9/2014

Qordhowi, Y. (2007). Halal dan Haram dalam Islam. Diterjemahkan oleh Tim Kuadrandari Halalwal Haram fil Islam. Jabal. Bandung

Samani, Muchlas dan Hariyanto. (2012). Konsep dan Modal Pendidikan Karakter. Bandung : PT. Remaja Rosdakarya.

Syukir, A. (2012). Qurban Antara Syari’ati dan Haqiqi. Dipetik tanggal 22

November 2015 dari https://asmunisyukir.wordpress.com/hakikat/qurbanantara-syariati-dan-haqiqi/

https://id.wikipedia.org/wiki/Penyakit_koronavirus_2019\#cite_note-8 diakses tg1 27/07/2021 https://www.kemkes.go.id/folder/view/full-content/structure-faq.html diakses tgl 27/07/2021 